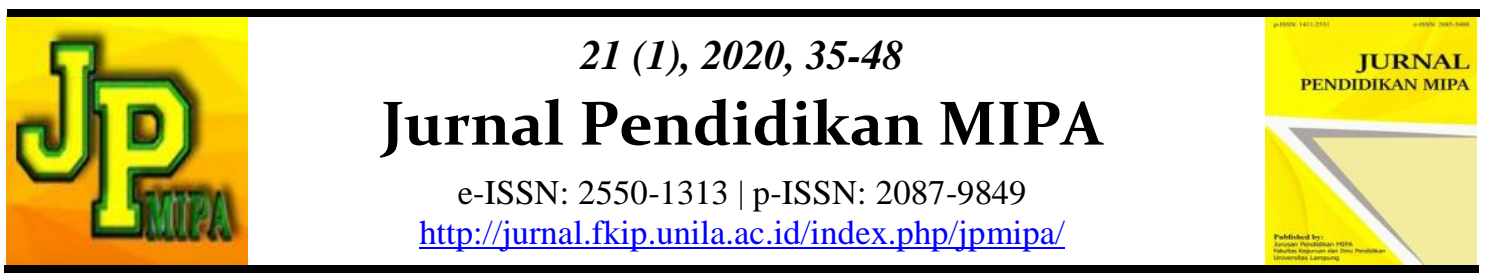

\title{
High School Mathematics Teacher's Ability in Developing Mathematical Literacy Instrument: A Study in East Lampung Regency
}

\author{
Mella Triana, Widyastuti, Erimson Siregar \\ Department of Mathematics and Science Education, Universitas Lampung, Indonesia
}

\begin{abstract}
High School Mathematics Teacher's Ability in in Developing Instruments of Mathematical Literacy Test: Study in Lampung Timur Regency. This study aims to describe the ability of high school mathematics teachers in East Lampung Regency in developing instruments of mathematical literacy test. This research is a descriptive study with 19 respondents of high school mathematics teachers. The research data were obtained through test, performance test and questionnaires. Data analyzed using data reduction, data presentation and conclusion. The results showed that: a) $63.16 \%$ teachers only able to create routine problem which measure employing stage in mathematical process; b) male teachers with more than 25 years teaching experience are only able to develop 5.26\% mathematical problems which measure formulating stage; c) Reasoning and argument is the fundamental mathematics skills that was rarely measured in the developed instrument; d) using symbolic, formal and technical language and operations is the most frequently skills that is measured in the developed instrument.
\end{abstract}

Keywords: mathematical literacy instrument, high school teacher, descriptive research.

Abstrak: Kemampuan Guru Matematika SMA Kabupaten Lampung Timur dalam Mengembangkan Instrumen Tes Literasi Matematis. Penelitian ini bertujuan untuk mendeskripsikan kemampuan guru Matematika SMA Kabupaten Lampung Timur dalam mengembangkan instrumen tes literasi matematis. Penelitian ini merupakan penelitian deskriptif dengan responden sebanyak 19 orang guru matematika SMA. Data penelitian diperoleh melalui instrument tes, tes unjuk kerja serta angket. Data dianalisis dengan tahapan reduksi data, penyajian data dan penarikan kesimpulan. Hasil penelitian menunjukkan bahwa a) $63,16 \%$ soal yang dibuat oleh guru adalah soal rutin pada tahapan proses matematis employ, b) Guru laki-laki dengan pengalaman mengajar lebih dari 25 tahun hanya mampu mengembangkan 5,26\% soal matematika dengan proses matematis formulate; c) Kemampuan dasar matematis yang paling minim dimunculkan pada soal yang dikembangkan oleh guru adalah penalaran dan argumentasi; d) penggunaan operasi dan bahasa simbolik, formal dan teknis adalah kemampuan yang paling sering diukur oleh guru pada instrument yang dikembangkan.

Kata kunci: instrumen literasi matematis, guru SMA, penelitian deskriptif.

Mella Triana

Email: mellatriana@yahoo.com
DOI: http://dx.doi.org/10.23960/jpmipa/v21i1.pp35-48

Received: 09 March 2020

Accepted: 23 June 2020 


\section{- INTRODUCTION}

Teachers are professional educators with the main task of educating, teaching, guiding, directing, training, and evaluating students in early childhood education through formal education, basic education, and secondary education. Based on that rule, one of the obligations of the teacher as a professional educator is to evaluate learning outcomes as the indicator for the accomplishment of learning objectives and the interpretation of subsequent improvement in the learning process (Undang-Undang Guru dan Dosen Nomor 14, 2005). This evaluation prevails for every subject in school including mathematics. One of high school mathematics learning objective states is "students can use reasoning on the nature, manipulate mathematics both in simplification, and analyze components that exist in solving problems in the context of mathematics and outside mathematics (real life, science, and technology) which includes the ability to understand the problems, build mathematical models, solve models and interpret the solutions obtained including in order to solve real problems in everyday life" (Permendikbud Nomor 59, 2014). The ability that must be mastered by students in the learning objectives are the ability to understand problems, make mathematical models, solve and interpret solutions, which relate to the definition of mathematical literacy.

Mathematical literacy according to the OECD (2013) is "individual's ability to formulate, employ, and interpret mathematics in various contexts. This includes mathematical reasoning and uses mathematical concepts, procedures, facts and mathematical tools to describe, explain and predict phenomena". It states the individual's ability to estimate and interpret data, solve everyday problems, provide arguments in numerical, graphical, and geometric forms, and communicate using mathematics (Ojose, 2011). Someone who has mathematical literacy will understand which mathematical concepts are relevant to the problem then formulate the problem into its mathematical form and solve the mathematical model. This process includes activities of connecting, formulating, determining, reasoning, and other mathematical thinking processes (Sari, 2015). Mathematical literacy refers to three mathematical processes, which are formulating, employing and interpreting. These three things require a mathematical process that describes how individuals connect the context of a problem with mathematics and solve the problem. The mathematical process in mathematical literacy involves seven basic mathematical abilities (fundamental mathematical capabilities). The seven basic mathematical abilities are communication, mathematizing, representation, reasoning and argument, devising strategies for solving problems, using symbolic, formal language and operations, and using mathematical tools (OECD, 2013).

Mathematical literacy is an important ability that must be possessed by students to reach mathematics learning objectives but the achievement of Indonesian students' mathematical literacy competencies is in low level. This is shown by the results of the PISA (Program for International Student Assessment) study which measures the mathematical literacy abilities of students. In the 2015 PISA study, the average scores of Indonesian student's mathematical ability were 386 while in 2018 study were 379 . PISA results in 2018 showed that Indonesian students' math scores decreased by 7 points from the previous measurement (OECD, 2019). Nizar, Putri, \& Zulkardi (2018) reported that the low achievement of PISA study was caused by students rarely accustomed to working on questions that contained context, not able to work on highlevel problems solving. 
Based on the 2019 Puspendik data it is known that the result of national exam for High School students in Lampung Province, mathematics subjects got the lowest average value with the percentage of students who answered correctly on questions that measure the ability to solve non-routine problems is only $1.84 \%$. East Lampung Regency as the largest district in Lampung province with 24 sub-districts, has the results of national exam for mathematics scores in high school level which indicate that most of high school students in East Lampung have not been able to solve contextual or nonroutine problems. This is known from the percentage of students who answered correctly on questions that measure students' ability to solve non-routine problems related to arithmetic sequences or rows only by $0.98 \%$; solving contextual problems related to algebraic function derivatives by $3.09 \%$; solving contextual problems related to multiplication $1.37 \%$. This means the ability of high school students in East Lampung regency to formulate, implement, and interpret mathematics problems in various contexts is still low or in other words the achievement of students' mathematical literacy abilities is in low level (Kemendikbud, 2019).

Pulungan (2014) states that the successful achievement of students' mathematical literacy competencies will be largely determined by the ability of the teacher to develop, and use the measurement tools that have been constructed in the right way, as well as the ability to analyze the information generated by the measuring instrument. Therefore, a teacher must have the knowledge and ability to develop mathematical literacy test instruments so that students will be familiar with the experience of working on mathematical literacy questions.

In fact, the teachers have lack information about mathematical literacy. These constraints make teachers not aware of mathematical literacy competencies, so there is no mathematical literacy assessment yet, teachers also still do not understand how to measure mathematical literacy competencies which are the goals of mathematics learning (Pulungan, 2014). This is also in line with Budiono's research (2016) of nine mathematics teachers and an analysis of 120 items of junior high school mid test instruments in Way Kanan district in the academic year of 2015/2016. The results showed that: (1) teachers did not understand mathematical literacy and had not compiled an assessment instrument based on 100\% mathematical literacy, (2) 100\% mid test instruments compiled by teachers had a low level of mathematical literacy ability. This shows that the ability of teachers to develop literacy test instruments is still low.

A person's mathematical literacy ability can be influenced by several factors. Research by Juhaevah (2017) and Lastuti et al (2018) shows that gender differences can affect students' mathematical literacy abilities. The literacy ability of male students is higher than female students. This is reinforced by the PISA results which show that the average score of male students is 11 points higher than the average score of women (OECD, 2014). Gender differences can be a differentiating factor in someone's thinking and determining the problem solving (Nur \& Palobo, 2018). Based on this, it is suspected that gender will influence the ability of teachers to develop literacy test instruments. Besides gender, experience also contributes to individual performance.

Eliyanto \& Wibowo (2013) suggested that the high-level experience and the more often a person does the same job, the more skilled and faster in completing the work. The multiple types of work a person does, caused his work experience in getting richer and broader, and increased the performance. Therefore, the experience gained by the teacher while teaching at school will certainly be very influential in achieving results. The higher the teaching experience of a teacher, the better his ability to work. This is 
confirmed by the results of research by Eliyanto \& Wibowo (2013) which show that teaching experience has a positive and significant influence on teacher professionalism. Therefore, teaching experience is thought to have contributed to the teacher's ability to develop mathematical literacy test instruments. Based on the problems described above, this research aims to describe the ability of mathematics teachers of senior high school in Lampung Timur Regency in developing mathematical literacy test instruments.

\section{- METHOD}

This research is a descriptive research. The study was conducted in September 2019 with the research subjects were 19 from 140 high school mathematics teachers in East Lampung regency. The research procedure is the preparation of a technical plan and literature review, the development of instruments, data collection, data analysis of the teacher's ability to develop literacy test instruments, drawing conclusions.

Data collection techniques used were tests and questionnaires. The test used in the form of a teacher's understanding test about the principles of the development of mathematical literacy instruments and performance tests to measure the ability of teachers in developing mathematical literacy test instruments. The questionnaire that were given contains a self-qualification statement about the principles of instrument development, mathematical literacy, mathematical instrument literacy and the tendency of independent self-development.

Data analysis techniques in this study used the model of Miles and Huberman (Sugiyono, 2016), through the stages of data reduction, data presentation, and drawing conclusions. Data reduction is focused on three aspects, which are the ability of teachers to apply the principles of developing test instruments, instruments made whether to contain the mathematical processes required in mathematical literacy (formulate, employ and interprate) and what mathematical abilities are raised in the problem.

\section{- RESULT AND DISCUSSION}

In this study, a test was conducted to measure the teacher's knowledge about the mathematical literacy test and its development procedures. The result of the test formulate using average score in terms of gender and teaching experience, which is shown in Figure 1.

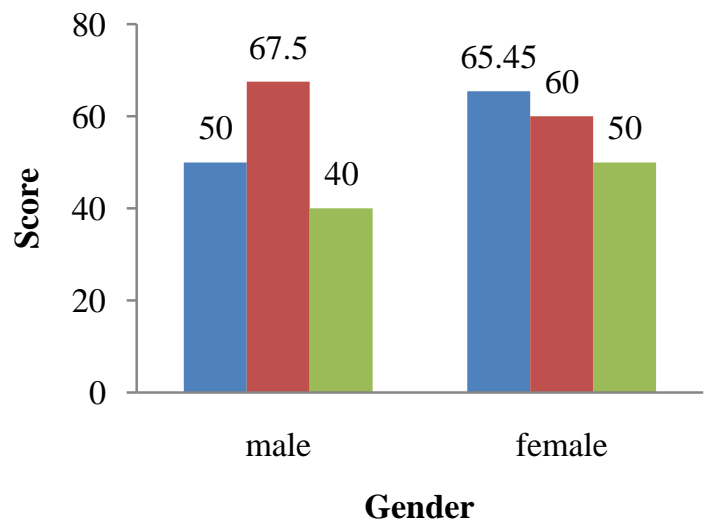

Figure 1. Average scores in terms of gender and teaching experience for teaching experience less than 10 years (blue), $10-25$ years (red), and more than 25 years (green). 
Based on Figure 1, for male teachers in the 10-25 years teaching experience span showed the highest average score. It means that male teachers have better knowledge about the mathematical literacy test and its development procedures in the productive period. Data in Figure 1 also showed that for female teachers, the highest average score appeared in the range of teaching experience $<10$ years. This means that the best knowledge to developed mathematical literacy test for female teacher is in adaptive period. However, it is known that in the range of teaching experience $<10$ years, female teachers have better abilities than male teachers while the average score of the ability of male teachers with teaching experience between 10 to 25 years is higher than the average score of female teacher. This means that in the adaptive time span, female teachers have better abilities than male teachers while male teachers in productive ranges have better abilities than female teachers. This phenomenon supported by Klassen \& Chiu (2010) which stated that teachers' years of experience showed nonlinear relationships with self-efficacy factors, increasing from early career to mid-career and then falling afterwards. Moreover, their research result showed that female teachers had greater workload stress, greater classroom stress from student behaviors, and lower classroom management self-efficacy.

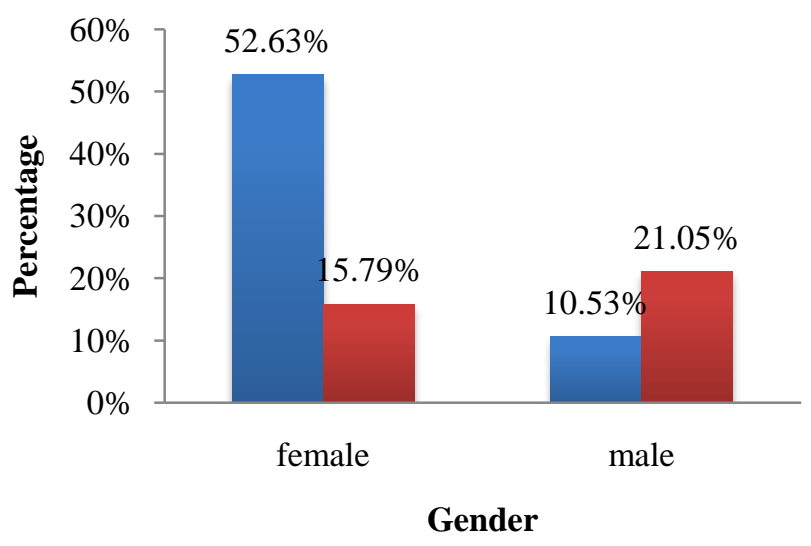

Figure 2. Percentage of types of questions made by teachers in terms of gender. Routine (blue) and non-routine (red).

Based on Figure 2, the largest percentage of questions made by teachers is still a routine problem. It shows from the percentage type of question that less than $25 \%$ test developed by both male dan female teachers can be categorized as non-routine problem. However, only $36,84 \%$ teachers could make non-routine questions and dominated by male teachers. In this case, male teachers are preferable in making non-routine problems than female teachers. As stated by Kyei, Apam, \& Nokoe (2011) that there is gender difference in the outcome of mathematics examinations with boys performing better than girls which ascertained from both students and teachers. Another result also noted by Nur \& Palobo (2018) that gender differences can be a differentiating factor in someone's thinking and determining the problem-solving process. Furthermore, Meece explained that male teachers tend to be more authoritative and instrumental whereas female teachers tend to be more supportive and expressive (Duffy, Warren, and Walsh, 2002).

Others research showed the negative effect of having a female teacher on math on math test scores of female students seem to disappear for students taught by female 
teachers with a strong math background (Antecol, Eren, \& Ozbeklik, 2015). This means that teacher's gender could affect student's achievement in math but profound material mastery would give greater effect. Sari \& Basarir (2016) state that what should actually be questioned with regard to the quality of teacher in education is how teachers teach in teaching-learning process; to what extent they improve students from cognitive, affective, social and emotional aspects and to what extent they consider themselves responsible rather than their gender. It is clear that emphasizing gender-aware approaches in teacher training will provide significant benefits in this regard.

The routine questions are the questions that are more often made by teachers in each range of teaching experience. This trends also showed in Budiono's research (2016) that 84 out of 120 questions or $70 \%$ of the mid test instruments for mathematics subjects compiled by teachers in Way Kanan regency are still classified as level 1 at the level of literacy ability. Most of the questions made by teachers only measure the student's ability to use their knowledge to solve routine problems, and mathematics problems in a general context.

Based on teaching experience, Figure 3 provides information that teachers who are productive in developing both routine and non-routine mathematical problems are teachers with teaching experience less than 10 years. The best span of teaching experience in producing non routine problem is also the less than 10 years range. It is also known that teachers with more than 25 years of teaching experience only can make $0 \%$ non-routine questions. However, from Figure 3 it is also showed that the routine questions was more often made by teachers in each range of teaching experience.

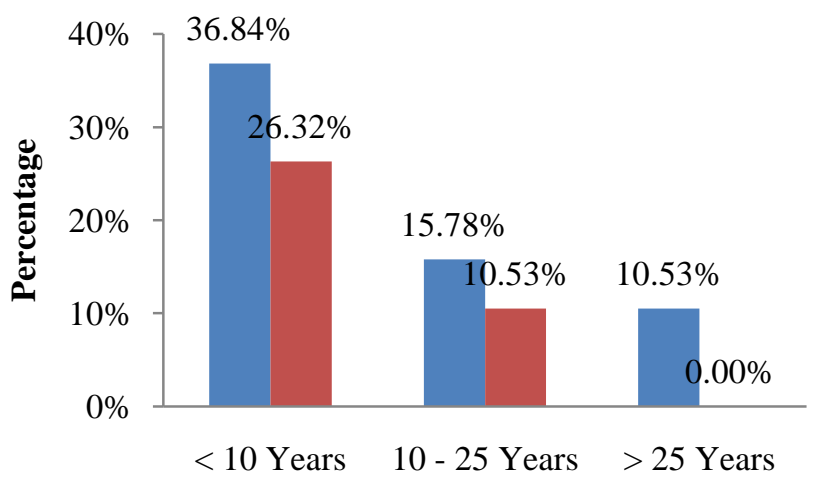

Teaching Experience

Figure 3. Percentage of types of questions made by teachers in terms of teaching experience. Routine (blue) and Non-routine (red).

In general, the ability of teachers to make mathematical literacy questions is illustrated in Table 1.

Table 1. Percentage of types of questions made by teachers in terms of teaching experiences and gender

\begin{tabular}{clcc}
\hline & & \multicolumn{2}{c}{ Type of Test } \\
\hline Teaching Experience & Gender & Routine & Non-Routine \\
\hline \multirow{2}{*}{$<10$ years } & Female & $31.58 \%$ & $26.32 \%$ \\
\cline { 2 - 4 } & Male & $5.26 \%$ & $0.00 \%$ \\
\hline
\end{tabular}




\begin{tabular}{clcc}
\hline \multirow{2}{*}{$10-25$ years } & Female & $5.26 \%$ & $0.00 \%$ \\
\cline { 2 - 4 } & Male & $10.53 \%$ & $10.53 \%$ \\
\hline \multirow{2}{*}{$>25$ years } & Female & $5.26 \%$ & $0.00 \%$ \\
\cline { 2 - 4 } & Male & $5.26 \%$ & $0.00 \%$ \\
\hline
\end{tabular}

Based on Table 1, in the range of teaching experience of $<10$ years, female teachers have better abilities than male teachers in developing mathematical problems. Both male and female teachers in this span of teaching experience dominantly developed routine problems. In the range of teaching experience of $10-25$ years, the ability of male teachers in developing mathematical problems is better than female teachers while in the range of teaching experience $>25$ years, there is no difference between male and female teachers in developing mathematical problems.

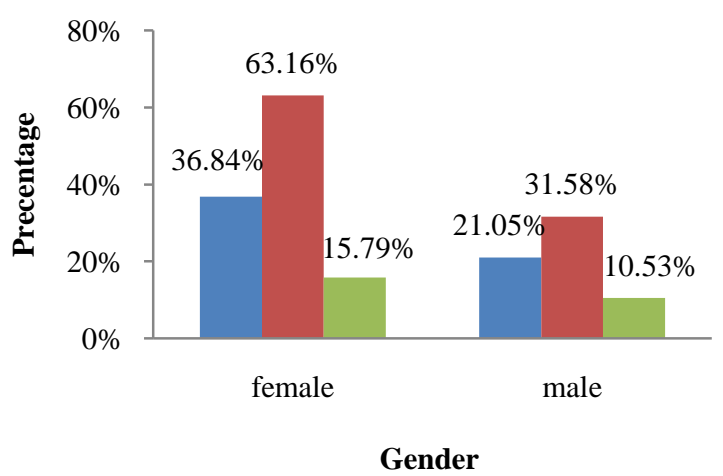

Figure 4. Percentage of teachers' ability to measure the mathematical process in a mathematical literacy test in terms of gender. Formulate (blue), employ (red) and interprate (green).

Based on Figure 4, female teachers have higher percentage in developing questions for every mathematical process than male teachers. It means that female teachers have better ability to measure the mathematical process in a mathematical literacy test. It is also known that mathematical problems made by both male and female teachers are dominated at the mathematical process of employing and the interprate stage is a mathematical stage that is minimal developed by both male and female teachers.

Table 2. Percentage of teacher's ability to emerge the mathematical process in mathematical literacy tests in terms of teaching experience

\begin{tabular}{cccc}
\hline \multirow{2}{*}{ Teaching Experience } & \multicolumn{3}{c}{ Mathematical Process } \\
\cline { 2 - 4 } & Formulate & Employ & Interprate \\
\hline$<10$ years & $31.58 \%$ & $63.16 \%$ & $21.05 \%$ \\
\hline $10-25$ years & $15.79 \%$ & $26.32 \%$ & $5.26 \%$ \\
\hline$>25$ years & $10.53 \%$ & $5.26 \%$ & $0.00 \%$ \\
\hline
\end{tabular}

Based on Table 2, the most common mathematics questions made by teachers in each range of teaching experience are still in the mathematical process of employing. It is also known that the interprate stage is the mathematical stage which less developed 
by teachers in each range of teaching experience. Teachers in range of $<10$ years teaching experience show the highest percentage in all mathematical process. It means that teachers in the adaptive period more productive in developing mathematical problem which measure the mathematical process in mathematical literacy.

Table 3. The percentage of teacher's ability to emerge the mathematical process in a mathematical literacy test in terms of teaching experience and gender

\begin{tabular}{cllcc}
\hline \multirow{2}{*}{ Teaching Experience } & \multirow{2}{*}{ Gender } & \multicolumn{3}{c}{ Mathematical Process } \\
\cline { 3 - 5 } & & Formulate & Employ & \multirow{2}{*}{ Interprate } \\
\hline \multirow{2}{*}{$<10$ years } & Female & $31.58 \%$ & $57.89 \%$ & $26.32 \%$ \\
\cline { 2 - 5 } & Male & $0.00 \%$ & $5.26 \%$ & $0.00 \%$ \\
\hline \multirow{2}{*}{$10-25$ years } & Female & $0.00 \%$ & $5.26 \%$ & $0.00 \%$ \\
\cline { 2 - 5 } & Male & $15.79 \%$ & $21.05 \%$ & $5.26 \%$ \\
\hline$>25$ years & Female & $5.26 \%$ & $5.26 \%$ & $0.00 \%$ \\
\cline { 2 - 5 } & Male & $5.26 \%$ & $0.00 \%$ & $0.00 \%$ \\
\hline
\end{tabular}

Based on Table 3, it is known that female teachers with $>10$ years of teaching experience have the ability to make mathematical literacy problems. Whereas in the span of $10-25$ years, male teachers have better abilities than female teachers. Female teachers in adaptive teaching experience have better abilities than male teachers in developing mathematical literacy test while male teachers in productive teaching experience have better abilities than female teachers. The mathematical process of employing is the most frequent mathematical process that appears on questions made by teachers both by female teachers and male teachers. Male teachers with more than 25 years of teaching experience are only able to develop mathematical problems with a mathematical formulate process.

Table 4. The percentage of teacher's ability emerge the fundamental mathematical capabilities in the mathematical literacy test in terms of gender

\begin{tabular}{lcc}
\hline \multicolumn{1}{c}{ Fundamental Mathematics Skills } & Male & Female \\
\hline Mathematising & $21.05 \%$ & $36.84 \%$ \\
\hline Communication & $15.79 \%$ & $21.05 \%$ \\
\hline $\begin{array}{l}\text { Using symbolic, formal and technical language and } \\
\text { operations }\end{array}$ & $26.32 \%$ & $42.11 \%$ \\
\hline Representation & $15.79 \%$ & $26.32 \%$ \\
\hline Reasoning and argument & $10.53 \%$ & $0.00 \%$ \\
\hline Devising strategies for solving problems & $15.79 \%$ & $15.79 \%$ \\
\hline
\end{tabular}

Based on Table 4, it is known that the mathematical basic abilities rarely raised in mathematics problems made by both female and male teachers are Reasoning and argument. While the basic mathematical abilities that most often appear on questions developed by teachers are using symbolic, formal and technical language and operations. This indicates that the questions created by the teacher are still limited to measure the mathematical procedures in the form of mathematical expressions to apply the problem-solving algorithm. This is related to the research results by Ahmad, Suherman, \& Maulana (2018) that the ability of teachers to solve mathematical literacy problems for levels 1 to 3 is good, but for level 4 or above it is still low. This means that 
the teacher's ability to solve problems that only require mathematical procedures (levels 1-3) is good, but the teacher's ability is still low in solving problems level 4-6 which relate to problems with complex situations that require higher reasoning. Another study by Botha \& Putten (2018) revealed that some teachers find it difficult to go beyond intra-mathematical problems and that the modelling process in general, and the function and direction of mathematization in particular, are not well understood.

Table 5. The percentage of teacher's ability emerge the fundamental mathematical capabilities in the mathematical literacy test in terms of teaching experience

\begin{tabular}{lccl}
\hline \multicolumn{1}{c}{ Fundamental Mathematics Skills } & $\begin{array}{c}<\mathbf{1 0} \\
\text { years }\end{array}$ & $\begin{array}{c}\mathbf{1 0 - 2 5} \\
\text { years }\end{array}$ & $\begin{array}{l}>\mathbf{2 5} \\
\text { years }\end{array}$ \\
\hline Mathematising & $31.58 \%$ & $15.79 \%$ & $10.53 \%$ \\
\hline Communication & $15.79 \%$ & $21.05 \%$ & $0.00 \%$ \\
\hline $\begin{array}{l}\text { Using symbolic, formal and technical } \\
\text { language and operations }\end{array}$ & $42.11 \%$ & $21.05 \%$ & $5.26 \%$ \\
\hline Representation & $31.58 \%$ & $10.53 \%$ & $0.00 \%$ \\
\hline Reasoning and argument & $5.26 \%$ & $5.26 \%$ & $0.00 \%$ \\
\hline Devising strategies for solving problems & $15.79 \%$ & $10.53 \%$ & $5.26 \%$ \\
\hline
\end{tabular}

Based on Table 5 it is known that the mathematical basic abilities rarely emerge in mathematics problems made by teachers in each range of teaching experience are reasoning and argument, while the basic mathematical abilities that appear most often in questions developed by teachers are using symbolic, formal and technical language and operations. It is also known that based on teaching experience, teachers with $<10$ years of teaching experience are superior to teachers in other teaching experience ranges in compiling mathematical problems that emerge the basic mathematical abilities. The greater percentage in almost all aspect of fundamental mathematics skills for teachers with $<10$ years of teaching experience showed the greatest performance in the beginning of teaching experience. It is also showed the teacher's greatest productivity gains during their first few years on the job (Rice, 2013). The study of Podolsky, Kini and Hammond (2019) show that teachers' effectiveness rises sharply in the first few years of their careers, and this upward trajectory continues well into the second and often third decade of teaching, with a steeper slope when teachers work in collegial settings.

Beginning teachers' experiences after their initial education at universities are critical for a successful career (Keskin, Çorlu, \& Ayas, 2018). Berliner (Keskin, Çorlu, \& Ayas, 2018) explained that teachers who begin their careers withlack of support and have limited professional development opportunities in their career, if do not quit the profession, will gain the experience but will neither become an expert nor turn out to be one of the exemplary figures in the profession. It indicates how important the opportunities to develop skills for teachers in their beginning of career because teacher's education is one of the main pillars of any educational system: its overarching role is to prepare suitably qualified teachers required by that system (Koech \& Mwei, 2019).

Furthermore, the teacher's ability to emerge fundamental mathematical abilities in terms of gender and teaching experience is presented in Table 5. Based on Table 5, in the range of teaching experiences $<10$ years, female teachers are superior to male teachers in compiling math problems that emerge the basic mathematical abilities. In this range, male teachers are only able to come up with problems with the ability of 
representation and reasoning and argument. In the span of 10 to 25 years, male teachers have better abilities than female teachers in developing questions that emerge the basic mathematical abilities. Whereas in the range of teaching experience $>25$ years, female teachers are superior to male teachers in developing mathematical problems to measure basic mathematical abilities. In general, only male teachers are able to make mathematical problems to measure reasoning and argument abilities.

Table 6. The percentage of teacher's ability emerge the fundamental mathematical capabilities in the mathematical literacy test in terms of gender and teaching experience

\begin{tabular}{lccccccc}
\hline \multirow{2}{*}{$\begin{array}{l}\text { Fundamental Mathematics } \\
\text { Skills }\end{array}$} & \multicolumn{2}{c}{$<\mathbf{1 0}$ years } & \multicolumn{2}{c}{$\mathbf{1 0 - 2 5}$ years } & \multicolumn{2}{c}{$>\mathbf{2 5}$ years } \\
\cline { 2 - 8 } & Male & Female & Male & Female & Male & Female \\
\hline Mathematising & 32 & 0 & 0 & 16 & 5 & 5 \\
\hline Communication & 16 & 0 & 0 & 16 & 5 & 5 \\
\hline $\begin{array}{l}\text { Using symbolic, formal and } \\
\text { technical language and } \\
\text { operations }\end{array}$ & 42 & 0 & 0 & 16 & 5 & 0 \\
\hline Representation & 26 & 5 & 5 & 5 & 0 & 0 \\
\hline Reasoning and argument & 0 & 5 & 0 & 5 & 0 & 0 \\
\hline $\begin{array}{l}\text { Devising strategies for } \\
\text { solving problems }\end{array}$ & 16 & 0 & 0 & 11 & 5 & 0 \\
\hline
\end{tabular}

In addition beside using tests, data were also collected using a questionnaire. The recapitulation of the results is illustrated in the following Table 7.

Table 7. Recapitulation of questionnaire results

\begin{tabular}{lccc}
\hline Questionnaire & Not Able & Quite Able & Able \\
\hline Principles of Instrument Development & $8.55 \%$ & $34.87 \%$ & $56.58 \%$ \\
\hline Mathematical Literacy & $40.79 \%$ & $50.00 \%$ & $9.21 \%$ \\
\hline Mathematical Literacy Instrument & $55.26 \%$ & $39.47 \%$ & $5.26 \%$ \\
\hline Self-development tendencies & $1.75 \%$ & $40.35 \%$ & $57.89 \%$ \\
\hline
\end{tabular}

Based on the results of the questionnaire, on the dimensions of mathematical literacy, $50 \%$ of teachers stated that they were quite capable while $40.79 \%$ said they were not able to mastery the mathematical literacy concept. The same thing also happened in the dimension of mathematical literacy instruments, 55.26\% of teachers said that they were not able to develop the mathematical literacy instrument. Both conditions indicate that the lack of ability and knowledge that is experienced by most of teachers in understanding and developing mathematical literacy test instruments. This is consistent with the Husna's research which states that the teacher's knowledge of mathematical literacy competencies is in low categories. In addition, mathematics literacy tests are very rarely used in schools, especially for high school students (Pulungan, 2014).

The lack of teacher understanding of mathematical literacy is also revealed by Umbara \& Suryadi's research (2019), which is that teachers are actually accustomed to applying context-based learning in the real world, even though the learning process has not reach the learning objectives optimally. Most teachers have poor understanding that related to mathematical content, basic mathematical competencies (fundamental mathematical capabilities) and mathematical processes. This indicates that the learning 
applied is not specifically aimed at developing mathematical literacy. Even though, Cappelli (Afifah et al., 2018) which states that the teacher plays a role in providing literacy activities and developing contextual teaching materials. They also need to understand the purpose of using literacy strategies in their classroom. Professional development and preservice courses can provide opportunities for teachers to use the strategies with content material, to conduct focused observations of lessons using literacy strategies, and to debrief what was observed (Adams \& Pegg, 2012).

Ojose (2011) explained that mathematics literacy does not imply detailed knowledge of calculus, differential equations, topology, analysis, linear algebra, abstract algebra, and complex sophisticated mathematical formulas, but rather a broad understanding and appreciation of what mathematics is capable of achieving. This can be revealed through implementation of competencies to be applied in the practical problems such as in social context. One of the topic that can be used in developing mathematics literacy is about social justice. Teaching for social justice in the mathematics classroom requires discernment between what 'should' be done to ensure accountability to the practices of the discipline and what 'could' be done to promote awareness of how those practices may be used to afford equity and access within the classroom (Brown, 2009).

Although the results of the study show a tendency for differences in the ability of teachers to construct mathematical literacy test instruments in terms of gender, equal opportunities need to be given to both female and male teachers to develop their abilities in constructing mathematical literacy test instruments. This will provide equal opportunities for students to contribute in learning and assessments that develop mathematical literacy skills. Martin \& Marsh (2005) concluded that academic motivation and engagement does not significantly vary as a function of their teacher's gender, and in terms of academic motivation and engagement, boys do not fare any better with male teachers than female teachers. It implies that, teacher's gender is not a problem for students to expand their ability. So that, equal chance should be given both for male and female teachers in any teaching experience span to improve their ability that concern with the knowledge and skills in the development of test instruments related to mathematical literacy through workshop, training, and mentoring activities

\section{- CONCLUSION}

Based on the results of research and discussion, the following conclusions are obtained: a) most teacher only able to create routine problem which measure employing stage in mathematical process while the interpreting stage was rarely developed; b) male teachers with more than 25 years teaching experience are only able to develop mathematical problems which measure formulating stage in mathematical process; c) female teachers in adaptive teaching experience have better abilities than male teachers in developing mathematical literacy test while male teachers in productive teaching experience have better abilities than female teachers; d) Reasoning and argument is the fundamental mathematics skills that was rarely measured in the developed instrument while using symbolic, formal and technical language and operations is the most frequently skills that is measured in the developed test. This indicates that the mathematical problem that were created are still limited to measure the mathematical procedures to apply the algorithm in solving the problem.

Suggestions that can be made based on the conclusions of this study are to improve teacher's ability that concern with the knowledge and skills in the development 
of test instruments and learning media related to mathematical literacy through workshop, training, and mentoring activities.

\section{- REFERENCES}

Adams, A. E. \& Pegg, J. (2012). Teachers' enactment of content literacy strategies in secondary science and mathematics classes. Journal of Adolescent \& Adult Literacy, 56(2), 151-161.

Afifah, A., Khoiri, M., \& Qomaria, N. (2018). Mathematics Preservice Teachers' Views on Mathematical Literacy. International Journal of Trends in Mathematics Education Research, 1(3), 92-94.

Antecol, H., Eren, O., \& Ozbeklik, S. (2015). The effect of teacher gender on student achievement in primary school. Journal of Labor Economics, 33(1), 63-89.

Botha, H. \& Putten, S. (2018). How mathematical literacy teachers facilitate mathematisation in modelling situations. African Journal of Research in Mathematics, Science and Technology Education, 22(1), 93-102.

Brown, Raymond. (2009). Teaching for social justice: exploring the development of student agency through participation in the literacy practices of a mathematics classroom. Journal of Mathematics Teacher Education, 12, 171-185.

Budiono, B. (2016). Analisis instrumen asesmen berbasis literasi matematika di SMP [Analysis of mathematical literacy-based assessment instruments in junior high schools]. Prosiding Seminar Nasional Matematika, 542-549. Retrieved January 22, 2020, from https://journal.unnes.ac.id/sju/index.php/prisma/article/view/ 21691.

Ahmad, D., Suherman, H. M., \& Maulana, H. (2018, April). Teacher mathematical literacy: case study of junior high school teachers in Pasaman. In IOP Conference Series: Material Sciences and Engineering (Vol. 335, No. 1, p. 012109). Retrieved April 22, 2020 from https://iopscience.iop.org/article/10.1088/ 1757899X/335/1/012109.

Departemen Pendidikan Nasional, (2005). Undang-Undang Nomor 14 Tahun 2005 Tentang Guru dan Dosen [Law Number 14 of 2005 concerning Teachers and Lecturers]. Jakarta: Depdiknas.

Duffy, J., Warren, K., \& Walsh, M. (2001). Classroom interactions: Gender of teacher, gender of student, and classroom subject. Sex roles, 45, 579-593.

Eliyanto \& Wibowo, U. B. (2013). Pengaruh Jenjang pendidikan, pelatihan dan pengalaman mengajar terhadap profesionaliseme guru SMA Muhammadiyah di Kabupaten Kebumen [Effects of education, training and teaching experience on the professionalism of muhammadiyah high school teachers in kebumen regency]. Jurnal Akuntabilitas Manajemen Pendidikan, 1(1): 34-47.

Juhaevah, F. (2017). Profil kemampuan berpikir reflektif siswa smp dalam mememecahkan masalah matematika standar PISA ditinjau dari perbedaan gender [Profile of reflective thinking skills of junior high school students in solving standard mathematical problems PISA in terms of gender differences]. Jurnal Matematika dan Pembelajaran, 5(2), 221-236. Retrieved January 20, 2020 from http://dx.doi.org/10.33477/mp.v5i2.770.

Kemendikbud. (2014). Peraturan Menteri Pendidikan dan Kebudayaan Republik Indonesia Nomor 59 Tahun 2014 Tentang Kurikulum 2013 Sekolah Menengah Atas/ Madrasah Aliyah [Regulation of the Minister of Education and Culture of the Republic of Indonesia Number 59 Year 2014 Regarding the 2013 Curriculum 
of Senior High Schools/Madrasah Aliyah]. Jakarta: Departemen Pendidikan dan Kebudayaan.

Kemendikbud. (2019). Hasil Ujian Nasional Tahun Pelajaran 2018/2019. Retrieved January 23, 2020, from https://hasilun.puspendik.kemdikbud.go.id/\#2019!sma! daya_serap!99\&99\&999!a\&03\&T\&T\&1\&!1!\&.

Keskin, Ö., Çorlu, M. S., \& Ayas, A. (2018). Voicing mathematics teachers: A holistic overview of their early career challenges. Educational Sciences: Theory \& Practice, 16, 331-371.

Klassen, Robert M.,Chiu, Ming Ming. (2010). Effects on teachers' self-efficacy and job satisfaction: Teacher gender, years of experience, and job stress. Journal of Educational Psychology, 102(3), 741-756.

Koech, Hellen C., \& Mwei, Philip K. (2019). How secondary school mathematics teachers perceive the effectiveness of microteaching and teaching practice in their preservice education. Humanities and Social Sciences Letters, 7(1), 46-55.

Kyei, L., Apam, B., Nokoe, K. S. (2011). Some gender differences in performance in senior high mathematics examinations in mixed high schools. American Journal of Social And Management Sciences, 2(4), 348-355.

Lastuti, F. A. O., Maharani, R. M., \& Pratini, H. S. (2018, February). Analisis Kemampuan Literasi Matematika Kelas VIII Menurut Gender. In Prosiding Seminar Nasional Pendidikan Matematika Etnomatnesia. Retrieved January 22, 2020, from http://jurnal.ustjogja.ac.id/index.php/etnomatnesia/article/view/2357.

Martin, Andrew., Marsh, Herb. (2005). Motivating boys and motivating girls: Does teacher gender really make a difference?. Australian Journal of Education, 49(3), 320-334. Retrieved May 01, 2020, from https://doi.org/10.1177\%2F000494410504 900308.

Nizar, H., Putri, R. I. I.; Zulkardi (2018). Developing PISA-Like Mathematics Problem Using the 2018 Asian Games Football and Table Tennis Context. Journal on Mathematics Education, 9(2), 183-194. Retrieved January 22, 2020, from https://ejournal.unsri.ac.id/index.php/jme/article/view/5246.

Nur, A. S., \& Palobo, M. (2018). Profil kemampuan pemecahan masalah matematika siswa ditinjau dari perbedaan gaya kognitif dan gender [Profile of students' mathematical problem solving abilities in terms of differences in cognitive and gender styles]. Kreano, Jurnal Matematika Kreatif-Inovatif, 9(2), 139-148.

OECD. (2013). PISA 2015 draft mathematics framework. Paris: OECD Publisher.

OECD. (2014). PISA 2012 results: What students know and can do - student performance in mathematics, reading and science (Volume I, Revised edition, February 2013). PISA: OECD Publishing.

OECD. (2016). PISA 2015 result in focus. Paris: OECD Publishing.

OECD. (2019). PISA 2018 results combined executive summaries volume I,II \& III. PISA: OECD Publishing.

Ojose, B. (2011). Mathematics literacy: Are we able to put the mathematics we learn into everyday use? Journal of Mathematics Education, 4(1), 89-100. Retrieved January 22, 2020, from http://educationforatoz.com/images/8.Bobby_Ojose Mathematics_Literacy_Are_We_Able_To_Put_The_Mathematics_We_Learn_Into Everyday_Use.pdf.

Podolsky, A., Kini, T. \& Darling-Hammond, L. (2019). Does teaching experience increase teacher effectiveness? A review of US research. Journal of Professional Capital and Community, 4(4), 286-308. 
Pulungan, D. A. (2014). Pengembangan instrumen tes literasi matematika model PISA [Development of the PISA model of mathematical literacy test]. Journal of Educational Research and Evaluation, 3(2), 74-78.

Rice, J. K. (2013). Learning from experience?: Evidence on the impact and distribution of teacher experience and the implications for teacher policy. Education and Finance Policy, 8(3), 332-348.

Sari, M., \& Basarir, F. (2016). Analyzing teachers' perceptions of "female teacher" and "male teacher" within traditional gender roles. International Journal of Education and Research, 4(3), 205-224.

Sari, R. H.N. (2015). Literasi matematika: Apa, mengapa dan bagaimana? [Mathematical literacy: What, why and how?]. Prosiding Seminar Nasional Matematika dan Pendidikan Matematika UNY 2015. 713-720. ISBN. 978-60273403-0-5.

Umbara, U. \& Suryadi, D. (2019). Re-Interpretation of mathematical literacy based on the teacher's perspective. International Journal of Instruction, 12(4), 789-806. 